\title{
Comparative Study on the Constitution Governing Movement between the Qajar Dynasty of Iran and the Late Qing Dynasty of China
}

\author{
Yang Yang \\ Southwest University, Chongqing, China \\ Email: yangkent78@qq.com
}

Received 30 October 2015; accepted 24 December 2015; published 30 December 2015

Copyright (C) 2015 by author and Scientific Research Publishing Inc. This work is licensed under the Creative Commons Attribution International License (CC BY). http://creativecommons.org/licenses/by/4.0/

\begin{abstract}
The constitution governing is the need of the times and the only way of the political modernization. Taking another ancient civilization in the world Iran's constitution governing tradition and the Chinese culture for constitution governing as comparative study, these factors such as the time, characters, events, thought and practice will be further activated and the similarities and differences of two countries' traditional culture about constitution governing will be compared through comparatively analyzing their historical backgrounds, their development process and their development's effect. So, their common and unique characteristics for constitution governing rules will be explored in this paper.
\end{abstract}

\section{Keywords}

Qajar Dynasty, The Late Qing Dynasty, The Constitution Governing, Constitutionalism

\section{Introduction}

The political modernization makes the modern society's governing pattern change from the government's single one rule to the government and society's multiple co-rule, and demands that the force power and the right power should balance to be distributed in the order framework to create a suitable co-rule way and bridge. So the constitutionalism and constitution is the precondition and foundation in the current situation and it is the only way to carry out the social governance through the constitution for the constitution governing. There was the constitution governing tradition in China for a long time. For one hundred years, the intellectuals pursued that it could 
be settled in our tradition to realize a strong country and better-off people, and to achieve a higher country and public's right and the better social life. There are different studies for the political practice of constitution governing for the one hundred years, such as studying it from the aspect of time, characters and events, or from the aspect of thought and practice as working-point. In fact, there is another research thinking, which takes other countries' constitution governing practice as a reference to carry out a comparative study. These factors such as the time, characters, events, thought and practice will be further activated and the similarities and differences of two countries' traditional culture about constitution governing will be compared through comparatively analyzing their historical backgrounds, their development process and their development's effect. So, their common and unique characteristics for constitution governing rules will be explored in this paper. To choose the Iranian constitution governing culture as a reference is because these two countries are the ancient civilizations in the world, are located eastern and have a heavy cultural foundation. China and Iran suffered a strong invasion at the beginning of the 19th century, both were seeking for a way to establish a strong country and better-off people at the end of the 19th century to the middle of 20th century and it became the foundation of the constitutionalism movement which was carried out from the top to down at the beginning of the 19th century. Comparing their constitution governing movement's history can help to understand the two countries and their constitutional governing movement's origin and tradition, thus bringing a new understanding for the Oriental society in the former political modernization era and in the era.

\section{Comparing Their Historical Backgrounds for Constitution Governing Movement}

The government in the late Qing Dynasty has already faced the difficulties like an arrow on the bowstring. From our domestic perspective, the bourgeois reformist headed by Kang Youwei and Liang Qichao put forward the requirements of the reform in the 1898 Reform Movement, which was the beginning of the constitution governing movement in China. The reformists actively promoted the constitution monarchy movement, but soon it was cracked down by the feudal conservative forces. The successive patriotic and national salvation movement happened in the later, especially the anti-armed uprising by bourgeois revolutionaries, forced the Qing government to face a huge pressure of constitutionalism. In January 29th 1901, that was 12 October of Guangxu twenty-six years, the Empress Dowager Cixi in Xi'an issued the edict of reform, which showed to change the law, broke the abuse, soyght the power and so on, to carry out the New Deal, which was laid the foundation for the 1905 Constitution-ism. From the international perspective, it was increasingly fierce the western legal culture dash against the autocratic China who was based on the natural economy, and the Opium War and a series of unequal treaties made China's sovereignty seriously damaged (Zhang, 2010). The social unrest in China had reached its peak and the political authority reached an unprecedented decline by the end of 19th Century. Although the Westernization Movement that its slogan is learning the skills to self-reliance promoted the process of China's early industrialization in a certain degree, it did not fundamentally touch the political system reform and achieve its purpose that made the country rich and its military force efficient. The 1900 Rebellion and Boxer Movement made the government of the late Qing Dynasty understand that there was no other way to choice and it was urgent to change the management rule model (Sun, 2011).

Iran was a traditional semi-feudal and semi-colonial Shiah monarchy country before the constitution governing movement. Due to the weak and corrupt of Qajar Dynasty, the Iran was bestially seized and exploited by British and Russian imperialism. British finished its economic control and aggression to Iran through its three agencies of the Indo-European telegraph office, the Imperial Bank of Persia and the Anglo Persian oil company. Because Russia is located near Iran, its colonial plunder for Iran is becoming more convenient and unscrupulous. The economic deterioration aggravated the social contradictions, the famine took place from 1903 to1904 and its inflation became the flash-point. The King Muzaffar Shah was force to issue the proclamations the Persian Great Charter on August 5, 1906 by the people's rebellion. The first session was held in October 1906 in the Iranian history and the first constitution of the Persian history was achieved as the supplementary terms of basic law were passed in this conference. The constitution governing movement in Iran from 1905 to1911 happened in the time that the western culture shocked Iran traditional order. The contradiction of the nationalism and the western colonialism, the contradiction of the democracy and tyranny in this period pushed forward the Iranian social contradictions and political confrontation. The constitution governing revolution would meet the need of times, so it was becoming a great attempt to establish a modern nation state and sovereign state for rebuilding the national power and rights (Li \& Wang, 2012). 


\section{Comparing Their Constitution Governing Movement's Process}

\subsection{The Beginning of Their Constitution Governing Movement}

The rise of constitutional movement in the late Qing Dynasty was closely related to the capitalism development, the upsurge of the bourgeois revolution, the government's new policy and other factors. The political goal that the reformists advocated the political reform was to establish a constitutional monarchy through summoning the parliament and drawing up the constitution. Under the promotion of constitutionalism reformists, the ideal of constitutional monarchy as a constitutional governance thought was popularly developing at the beginning of the 20th century in China, and the bourgeoisie's upper class and some gentry-merchants became the social foundation of constitutional monarchy ideal. The ordinary people and intellectuals understood the power of constitutionalism when the Russo-Japanese war was broken out in 1904, so the strong desire burst upon them that the ruling class would be carrying on the radical political reform in 1905. In this way, the influential officials at the central government agreed it, the governors at the local government supported it and the constitutionalism reformists spare no effort to propagated it, all these formed the powerful force to carry on the reform. The government in the late Qing dynasty intended to enter into the constitution governing era step by step.

The starting point to the Iranian constitution governing revolution was the famine and inflation from 1903 to 1904 years. The merchants and handicrafts-men lived so poor life that the Tehran religious leaders led more than 5000 people to escape into the Abdul Agim mosques and had been demonstrations against the impact of foreign goods for their home markets, against the government taxes and asked the king dismissed the prime minister Ian Dora and carry out the political and economic reforms. However, the king ostensibly agreed with it, and did not carry out its own reform program and continue to appoint the Prime Minister Ian Dora. And then, the mass demonstrations was broken in Tehran of 1906 years and the government shed the bloodshed that resulted in ten thousand people to took refuge in the British Embassy, the British agency Duff helped draft a resolution. The requirements were put forward to summon the parliament and the constitution governing movement is in full swing.

\subsection{The Development of Their Constitution Governing Movement}

The Imperial Conference had to be held in July 1905 by the late Qing government as they have faced to the increasingly high demands for constitutionalism and the pressure for constitutionalism reform. This conference discussed the constitutionalism issues, decided to send the five ministers to go abroad to study and favor reform starting from the official system. But the political reform of the government's separation of power in the late Qing Dynasty still actually revolved around the military department as the administrative center to deceive people. The constitutionalism reformers were not satisfied with such a reform measures, and then they organized the constitutionalism group to carry out a variety of activities, which promoted the constitution governing, to promote their ideal of constitution governing only in this way. With the development of the huge movement that ask to immediately summon the parliament throughout the country and the petition activities by the constitutional reform, the late Qing government eventually began to carry out the substantive constitutional reform measures, including the promulgation of the outline of Imperial Constitution and the establishment of the Argument Bureau and the Advisory Council.

The first session parliament was held in Iran in October 1906 and the king Mozaffar approved the Fundamental Law that was drafted in the constitutionalism conference in December 1906. The council later added the supplementary provisions in order to extending the legislative power of Parliament and to limiting the monarch's powers. The Mozaffar's son Muhammad Ali ascended the throne and he refused to sign the supplementary provision of the Fundamental Law, in essence, he was doing this to seize the fruits of constitutional revolution (Jiang, 2010). Thus, the Iranian people were angry, and they eventually forced him to sign the supplementary provision and pledge allegiance to the constitution. The Iranian constitution was entered a new stage so far. The interim council passed a new electoral law on 17th November, 1909 and elected a new parliament. The second Parliament was opened to pass the new constitution, which the structure of the second parliament is extremely unstable. The Parliament later split into two hostile forces that one is the moderates led by Haba Hani and the other is democratic led by Tachi Zada. Their competition consumed the limited political resources in Iran. The constitutionalism government was basically in a state of paralysis at the end of 1910 years. It was not only improving the deteriorating social situation, but also significantly increasing the social unrest, and made its people 
suffered the pain of war (Li \& Wang, 2012).

\subsection{The Termination of Their Constitution Governing Movement}

Since the late Qing government promulgated the outline of Imperial Constitution and announced the period of provisional constitution making for nine years, the constitutionalism reformist' petition had been temporarily subsided, but their demands to immediately establish the congress was again reached o a upsurge. The main purpose of the monarchy constitution making in the late Qing Dynasty was to counteract the revolution so as to maintaining the interests of the royal family and the vested group. The establishment of the Royal cabinet has exposed the evil that the late Qing government centralized their power in the name of constitutionalism, which caused reformist extremely dissatisfied with it, and the late Qing government announced to carry out the policy of state-owned railway lines, the various social contradictions was further intensified, and the Railway Project Crises was begun. The provinces in China rise in revolt and established the revolutionary government. It was resulted that the constitution governing movement was suspended in the late Qing Dynasty.

Through the Iranian fights against the King's subversion supported by Russia, the revolutionaries in Tabriz proposed to restore the constitution, held the new parliament and the slogan was put forward that the foreigners should be turned out of the Iran, who supported the king and the reactionaries. The constitutionalism reformists' army captured the capital and seized the power on July 13th, 1909. The second Council was held in November 1909, in which the interim government thought that revolutionary task has been completed. So it till maintained the monarchy and the Qajar Dynasty. They have decided to recruit a number of consultants and experts from the neutral state in order to putting the political and economic chaos of Iran in order. However, the constitutionalism revolution in Iran did not have a strong and powerful revolutionary party leadership and did not really mobilize or organize their peoples. So, the second parliament was forced to dissolve when the Russian army entered Tehran in 1911 and the constitutionalism governing revolution in Iran was over. From this, the main cause of the constitutional revolution's failure in Iran is the interference of foreign armed forces, and the main cause of its failure in the late Qing Dynasty is that its own constitutional movement accelerates the destruction's speed.

\section{Comparing Their Constitution Governing Movement's Effect}

The preparatory constitutionalism movement in the late Qing Dynasty dashed the absolute monarchy, severely weakened the traditional monarchy for thousands of years and was the beginning of entering into the political modern from feudal China. So, the culture of constitutional governing has been understood and popularized and people begin to know the political knowledge of the constitutionalism, the monarch republic, the democratic republic, the rule of law and so on. It was a formidable force for the political socialization which was from the feverish political conflict and the constitution governing movement. It laid a solid mass foundation of the development of the constitution governing thoughts and practices, and cultivated the more advanced political culture elite. Only in this way can the old system's reform and the political modernization standard be promoted.

The constitutionalism movement in Iran was a new movement of their power and right's redistribution. It limited and restricted the king's power and extended the people's rights. This was a breaking of the old feudal system, embodied with a significant feature of bourgeoisie. It was not only a profound ideological and cultural liberation movement in the Iranian history, but also a part of the constitution governing revolution movement in Asian of the early twentieth Century. It was not necessarily significant for the system's breaking as the special forces group Mawla to join, especially the high-level Mawla who played an important role in the constitutionalism movement, at the same time it was actually set for a major disaster that Shiites would be against the secularism and advocate the theocratic for a later (The Period of Qajar Dynasty, 2010).

\section{Conclusion}

Either Iran or China has already elaborated the constitution governing. Especially for the current situation, it is pointed out in the eighteen sessions of the fourth plenary session of the Communist Party of China that the major tasks are to improve a socialist system of laws with Chinese characteristics, in which the Constitution is taken as the core, to strengthen the implementation of the Constitution, to promote administration by law, to speed up building a law-abiding government, to safeguard judicial justice, to improve judicial credibility, to promote the public awareness of rule of law, to enhance the building of a law-based society, to improve team 
building and to sharpen the CPC's leadership in pushing forward rule of law, the country should be ruled in line with the Constitution to realize the socialist system of laws with Chinese characteristics and the country should be ruled in line with the Constitution to realize the rule of law. So the constitution governing has a soundly based policy. The fine social governing blueprint of plural co-governing will be gradually realized in the future of political practice because of the practice of constitution governing movement in advance and the current policy that is ruled in line with the constitution.

\section{References}

Jiang, Z. (2010). Research on the Current Political Reform and Development in Iran from Westernization Reform to the Islamic Revolution. Journal of Ningxia Social Science, 5, 84-86.

Li, R., \& Wang, T. (2012). Analysis of the Constitution Movement from 1905 to 1911 in Iran. Journal of Inner Mongolia University for Nationalities, 4, 71-74.

Sun, G. H. (2011). The Reason for the Constitutionalism’s Failure in the Late Qing Dynasty. Knowledge Economy, 10, 109110.

The Period of Qajar Dynasty (2010). http://blog.sina.com.cn/s/blog_53745d410100mb9b.html

Zhang, D. H. (2010). An Analysis of the Provisional Constitution Making. Ph.D. Thesis, Zhengzhou: Zhengzhou University. 